\title{
REVIEW
}

\section{Why Do We Have Purkinje Fibers Deep in Our Heart?}

\author{
D. SEDMERA ${ }^{1,2}$, R. G. GOURDIE ${ }^{3,4,5}$ \\ ${ }^{1}$ Institute of Anatomy, First Faculty of Medicine, Charles University, Prague, Czech Republic, \\ ${ }^{2}$ Department of Cardiovascular Morphogenesis, Institute of Physiology Academy of Sciences of the \\ Czech Republic, Prague, Czech Republic, ${ }^{3}$ Virginia Tech Carilion Research Institute, Center for \\ Heart and Regenerative Medicine Research, Roanoke, Virginia, USA, ${ }^{4}$ Virginia Tech School of \\ Biomedical Engineering and Sciences, Roanoke, Virginia, USA, ${ }^{5}$ Department of Emergency \\ Medicine, Virginia Tech Carilion School of Medicine, Roanoke, Virginia, USA
}

Received October 21, 2013

Accepted October 29, 2013

\begin{abstract}
Summary
Purkinje fibers were the first discovered component of the cardiac conduction system. Originally described in sheep in 1839 as pale subendocardial cells, they were found to be present, although with different morphology, in all mammalian and avian hearts. Here we review differences in their appearance and extent in different species, summarize the current state of knowledge of their function, and provide an update on markers for these cells. Special emphasis is given to popular model species and human anatomy.
\end{abstract}

\section{Key words}

Cardiac conduction system • Specialized tracts • Gap junctions • Connexin

\section{Corresponding author}

D. Sedmera, Department of Cardiovascular Morphogenesis, Institute of Physiology, Academy of Sciences of the Czech Republic, Videnska 1083, 14220 Prague, Czech Republic. E-mail: dsedmera@biomed.cas.cz

\section{Introduction}

The cardiac conduction system (CCS) is defined as a network of specialized myocardial cells that generates the cardiac rhythm and assures a coordinated propagation of the electrical impulse for efficient contraction of the heart. In the adult mammalian heart, the CCS comprises the sinoatrial (SA) node, the internodal tracts, the atrioventricular node, the atrioventricular (His) bundle, its right and left branches, and the network of Purkinje fibers. While the functional equivalent of these components are present in some form in all vertebrate hearts (Sedmera et al. 2003), all morphologically distinct parts are present only in the heart of mammals. While development of the CCS has been subject to numerous reviews (Gourdie et al. 2003a,b, Christoffels et al. 2010, Burggren et al. 2013), little was written on the comparative morphology of its components in different species, with a few notable exceptions (Davies 1930, Davies et al. 1952, 1994). The goal of this overview is to put the Purkinje fibers into context of other CCS components, briefly describe the history of their discovery, provide functional insight into equivalent structures in the lower vertebrates, and then to focus in detail on their structure and function in the most popular model species of mammals and birds.

\section{Function of individual CCS components}

The SA node is the principal pacemaker of the heart. Under normal conditions it is the cardiac tissue that autonomously sets the rhythm of the heart beat. It is also subject to neurohumoral regulation, in particular by autonomous nervous system. This allows the heart to change its frequency in reaction to the functional status of the organism. Morphologically, it is organized into a three dimensionally complex compact structure 
(Mommersteeg et al. 2007, Fedorov et al. 2010), with specific connection points to the working atrial myocardium. In lower vertebrates, its function is contained in a compartment termed the sinus venosus (Koprla 1987, Jensen et al. 2012). New data on the cellular origin of the SA node from outside the traditional heart fields and role of Wnt signaling in recruitment of mesodermal cells into pacemaker lineage were recently reported by the Mikawa lab (Bressan et al. 2013).

\section{Atrial special conduction pathways}

The morphological distinction of specialized intra-atrial and internodal conduction pathways is a controversial topic. Some claim that there are tracts of Purkinje-like cells connecting the sinoatrial and atrioventricular node (James and Sherf 1971), while other agree that the conduction through the atria is anisotropic, see the main reason in holes caused by the entrance vessels (Betts et al. 2002, Ho et al. 2002). Our view is that these preferential conduction pathways, the best example of which is the interatrial bundle of Bachmann (Sedmera et al. 2006) can be explained by tissue geometry (pectinate muscles), in agreement with previous experimental data (Komuro et al. 1986), but are open to a marker that would distinguish cells within those tracts from the remaining atrial myocytes.

\section{The AV node}

The main function of the atrioventricular node is generation of a delay between activation (and ensuing contraction) of the atria and the ventricles. Due to its prolonged refractory period, it also serves as a filter against propagation of atrial tachyarrhythmias to the ventricles. In mammals, it shows a distinct morphological organization with specific cell phenotypes (Efimov et al. 1997, Aanhaanen et al. 2010). On the other hand, its morphological localization in birds is still obscure (Vicente-Steijn et al. 2011). In lower vertebrates, and during embryonic development, the function of delay generator is located in the atrioventricular canal region, a slowly proliferating, conducting and contracting portion of the cardiac tube that apparently retains its "primitive" phenotype - not following the pathway of chamber myocardium differentiation (Kirby 2007). The transcriptional regulation of these events has been recently uncovered, and $\mathrm{Tbx} 2, \mathrm{BMP}$ and $\mathrm{Tbx} 3$ are implicated in maintaining this transcription programme
(Mommersteeg et al. 2007, Aanhaanen et al. 2009, 2010). Electrophysiologically, this region shows a typical action potential shape (Arguello et al. 1986) and has a level of automaticity, which can manifest even in the embryo when the sinoatrial node is perturbed (Raddatz 1997). Interfaces between atria and node and node and His are marked by distinct transitions in connexin expression (Coppen et al. 1999, Gourdie and Sedmera 2008). Such abrupt changes in cellular coupling can play a role in AV delay generation in adult heart (Choi and Salama 1998).

\section{The His bundle}

Also known as the atrioventricular, or nonbranching bundle, it forms under normal conditions the only conductive pathway between the atria and the ventricles. It is a rapidly conducting tissue, with propagation velocity an order of magnitude faster than the working myocardium. As it traverses the atrioventricular fibrous plane, the bundle is insulated from the rest of the myocardium except of its proximal connection with the AV node and distal bifurcation into the left and right bundle branch.

\section{The bundle branches}

These form continuation of the His bundle, sharing many of its characteristics - rapid conduction speed, expression of gap junction protein connexin 40 (without co-expression of connexin43) and fibrous insulation from the working myocardium. This makes these bundles well suited to act as electrical cables, assuring rapid spread of the impulse through the ventricles. There is a notable asymmetry between the left and right bundle branch, the left being broad, in the mouse composed of multiple parallel isolated strands, while the right bundle being a narrow structure (Miquerol et al. 2004). It is likely due to optimization of source:sink ratio due to a marked asymmetry of the myocardial mass between the left and right ventricle.

\section{The Purkinje fibers}

The Purkinje fibers are the terminal part of the cardiac conduction system. They form a threedimensional subendocardial network originating from the bundle branches and their main function is to distribute the depolarization signal rapidly to the working myocardium. 


\section{Discovery of CCS}

The historical sequence, in which various CCS components were discovered, is in reverse order to the functional sequence of activation. In 1839 the Czech scientist Jan Evangeliste Purkinje described a pale network of cells in the sheep heart, and noted their microscopic characteristics, including the presence of one or two nuclei and cross striations, which made him, after some discussion, consider them a special form muscular tissue (Eliska 2006). It took more than fifty years before a Swiss physiologist His found the elusive connection between the atrial and ventricular myocardium, first by a series of cuts in the beating heart, then by detailed histological examination of the region, where such cuts led to atrioventricular block (Suma 2001). Over a decade later, Tawara (1906) connected this bundle by describing the atrioventricular node proximally and the bundle branches distally. The last component discovered was the sinoatrial node, described by Keith and Flack (1907) only a year later.

\section{Original description by Purkinje}

The original 1839 description by Purkinje was a part of a larger volume dealing with innervation of various organs and published in Polish. He followed up six years later in 1845 with a more detailed account in German, then the universal language of morphologists (Eliska 2006). There are few interesting points in this description that pertain to the present review. First, while the original species was sheep, he noted similar structures in the cow, pig, and horse. On the other hand, he was unable to see his cells in the human, dog, rabbit, or hare heart. This is an important reminder of the dangers of expecting that a functionally similar structure will look the same in different species (Robb 1965). Second, already by then he stated with certainty that these structures are not nervous fibers, especially significant in the context of general focus of his 1839 text on nervous tissue. Third, although he did seriously consider (due to their appearance) that these fibers could be cartilage, the presence of striations made him to decide that most likely these tissues were muscular. Nevertheless, later studies using various neuronal markers re-ignited the issue (Gorza et al. 1988, 1994), and the final word on myogenic nature of the CCS was provided using genetic lineage tracing techniques - showing its common origin with working cardiomyocytes (Gourdie 1995, Cheng et al. 1999).

\section{Differentiation of Purkinje fibers during development}

It has been shown in experimental studies in the chick heart, that ventricular Purkinje fibers share common origin with the surrounding ventricular myocytes and terminally differentiate during fetal period (Gourdie et al. 1995). In the avian model, it was convincingly demonstrated that the differentiation towards the conduction phenotype is time-sensitive, and locally produced endothelin-1 was demonstrated to be a key signaling molecule (Gourdie et al. 1998, Hyer et al. 1999, Takebayashi-Suzuki et al. 2000). The clonal relationship between the working ventricular myocytes and Purkinje myocytes observed in birds was confirmed recently in the mammalian (mouse) model (Meilhac et al. 2003, Miquerol et al. 2010). However, transcription or any other regulation governing this process in mammals is still elusive. While it was long speculated that ventricular trabeculae, forming during chamber differentiation as a means to increase myocardial mass prior to presence of coronary perfusion, form the precursors of the Purkinje network (de Jong et al. 1992, Sedmera et al. 2004), it is clear that not all the trabeculae will turn into Purkinje fibers - in fact, the majority will form trabeculae carneae, or "meaty" trabeculations composed largely of working myocardium, that we find on the inside of the ventricles. As noted above, our knowledge of mechanisms governing these decisions is woefully incomplete.

\section{Subendocardial and intramural network}

The Purkinje network is composed of two components: the subendocardial fibers, which have connection to the bundle branches and assure the apex-tobase activation of the ventricle, and a variably present intramural component. While the first is invariably reported, although with different morphology, from all mammalian and avian hearts, the latter, presumably accelerating transmural conduction, is only morphologically distinguishable in some species in particular sheep (Ryu et al. 2009) (Fig. 1), cow (Oosthoek et al. 1993), or pig (Fig. 2). In these animals, connection between the subendocardial and intramural network can be found at regular intervals (Fig. 6 in Oosthoek et al. 1993), and the extent in cow is about $80 \%$ of left ventricular wall thickness. On the other hand, despite quite extensive searches, no intramural fibers 
have been located in the mouse or human heart (Fig. 3). The presence of absence of the intramural component does not seem to be related to heart size, as some small animals - such as rats (Fazel et al. 1989, Thompson et al. 1990, Gourdie et al. 1992, 1993, Vuillemin et al. 1992) or chicken (Gourdie et al. 1993) (Fig. 4) do have intramural fibers - in the case of chicken clearly associated with the coronary arteries.
Functionally, the Purkinje fibers are characterized by a unique ion channel expression and faster conductivity in comparison to the working ventricular myocardium. This creates a local heterogeneity in conduction velocity and coupling, which can lead to re-entry. Their role as foci of arrhythmias was recently and extensively reviewed in (Boyden et al. 2010).
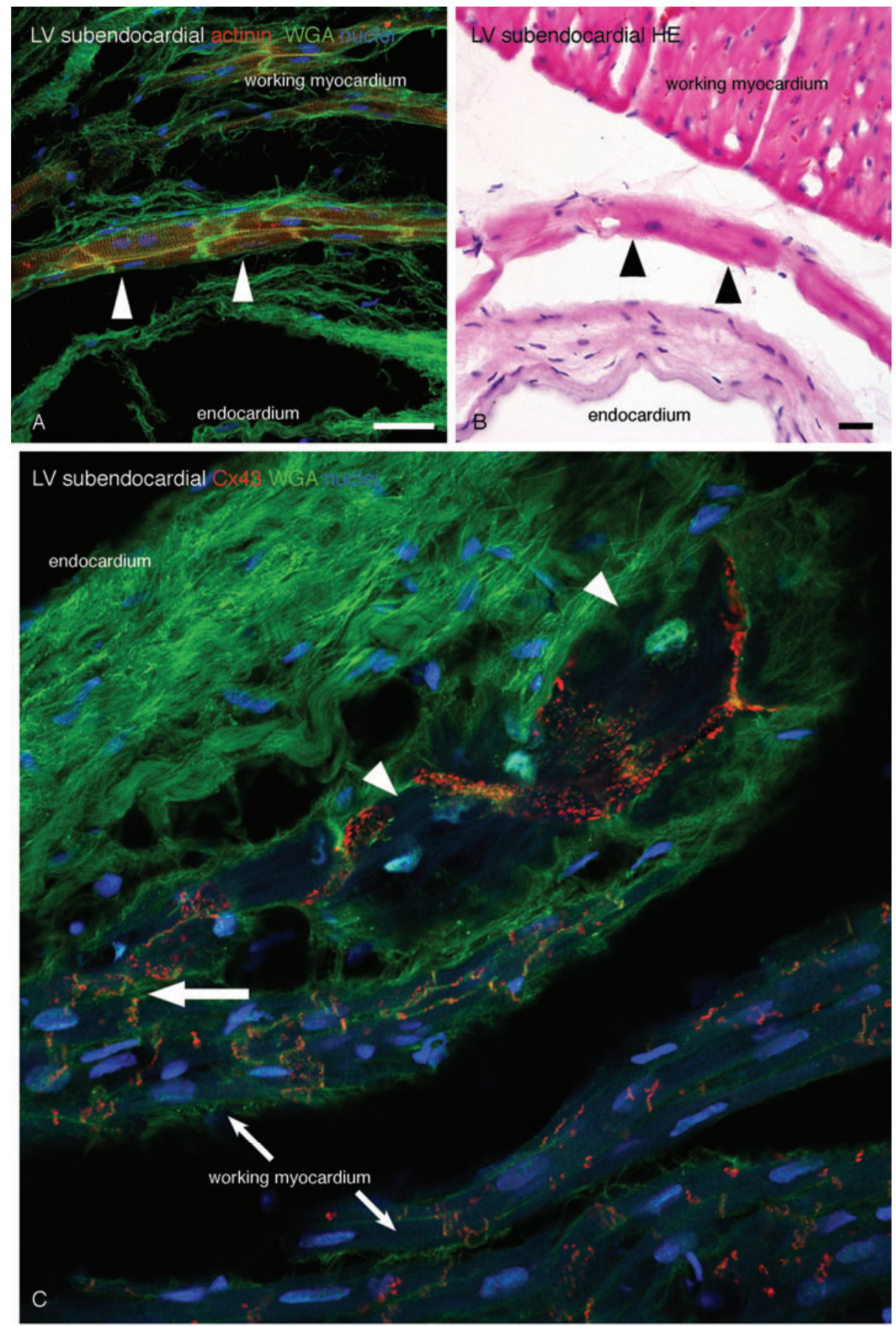

Fig. 1. Purkinje fibers in the sheep heart. A. Actinin staining shows that both the subendocardially located Purkinje fibers and the working cardiomyocytes have well organized contractile apparatus. B. Hematoxylin and Eosin staining shows clearly that they are larger than the working ventricular myocytes and their spatial and fibrous isolation. C. Staining for connexin43 shows very high density of these gap junction proteins on the entire cell membrane (compare to neighboring working myocardium where it is localized mostly at cell ends). Wheat germ agglutinin (WGA) staining highlights cell boundaries and fibrous tissue. Scale bars $25 \mu \mathrm{m}$. 

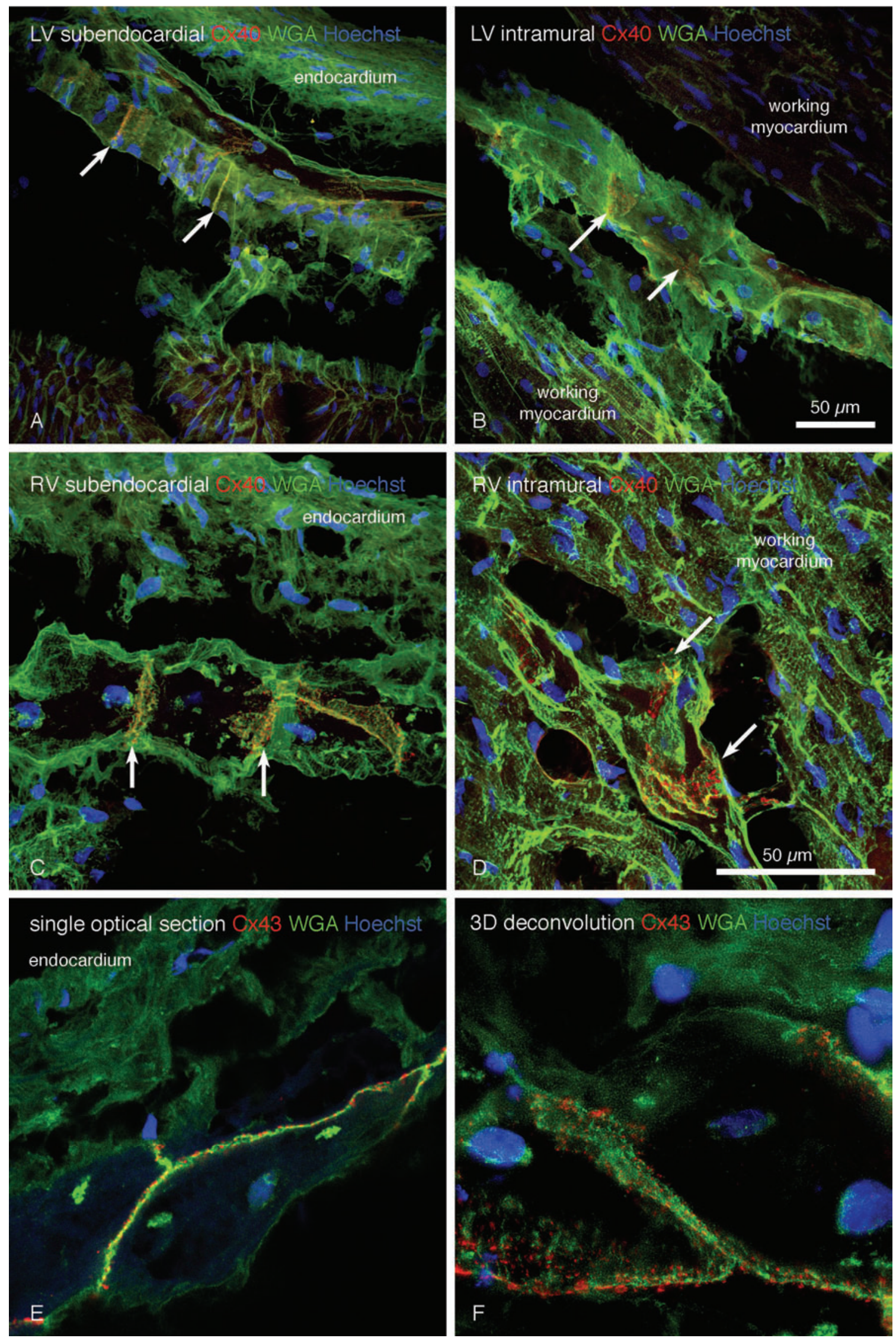

Fig. 2. Purkinje fibers in the pig heart. Connexin40 staining labels specifically both subendocardial (A) and intramural (B) Purkinje fibers. C and D: similar morphology with Connxin40 staining preferentially localized to cell ends and distribution of Purkinje cells is found also in the right ventricle. E and F: in contrast, Connexin43 staining is distributed in the entire cell surface. 

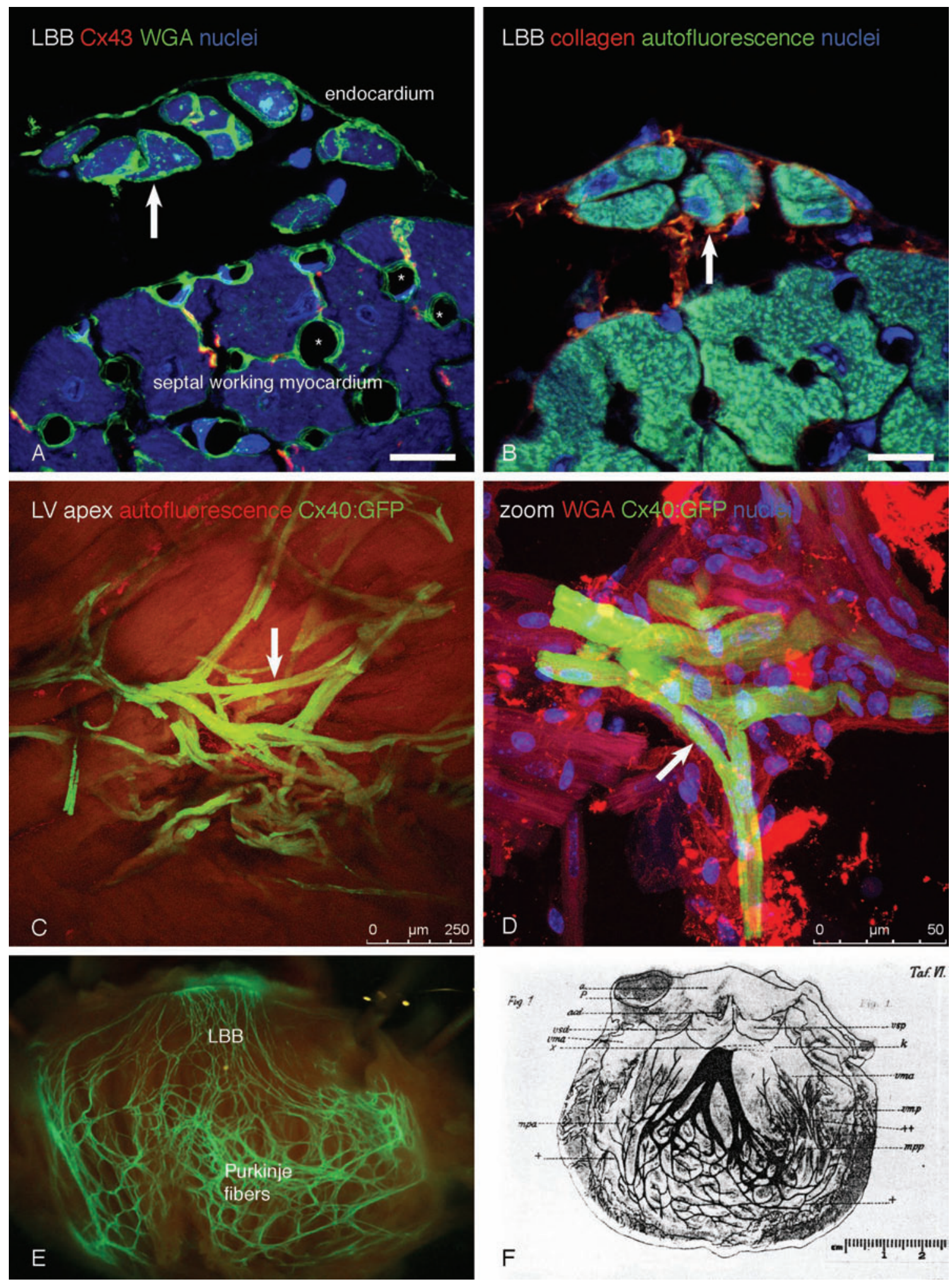

Fig. 3. Purkinje fibers in the murine heart. Panels $\mathbf{A}$ and $\mathbf{B}$ show the transition of Connexin43-negative left bundle branches into Purkinje fibers, which co-express both Connexin 40 and 43 . The tracts are spatially separated from the working myocardium and show a thin fibrous sheath. Scale bars $10 \mu \mathrm{m}$. Panels C and D visualize the Purkinje network using Connexin40:GFP transgenic mouse. The Purkinje network is formed by 1-3 cells thick strands of myocytes that are thinner but longer than the working myocytes. Panels $\mathbf{E}$ and $\mathbf{F}$ compare the arrangement of the entire left ventricular network in mouse (from Miquerol et al. 2004, withe permission) and human (Tawara 1906). In neither species were described any intramural Purkinje fibers. 

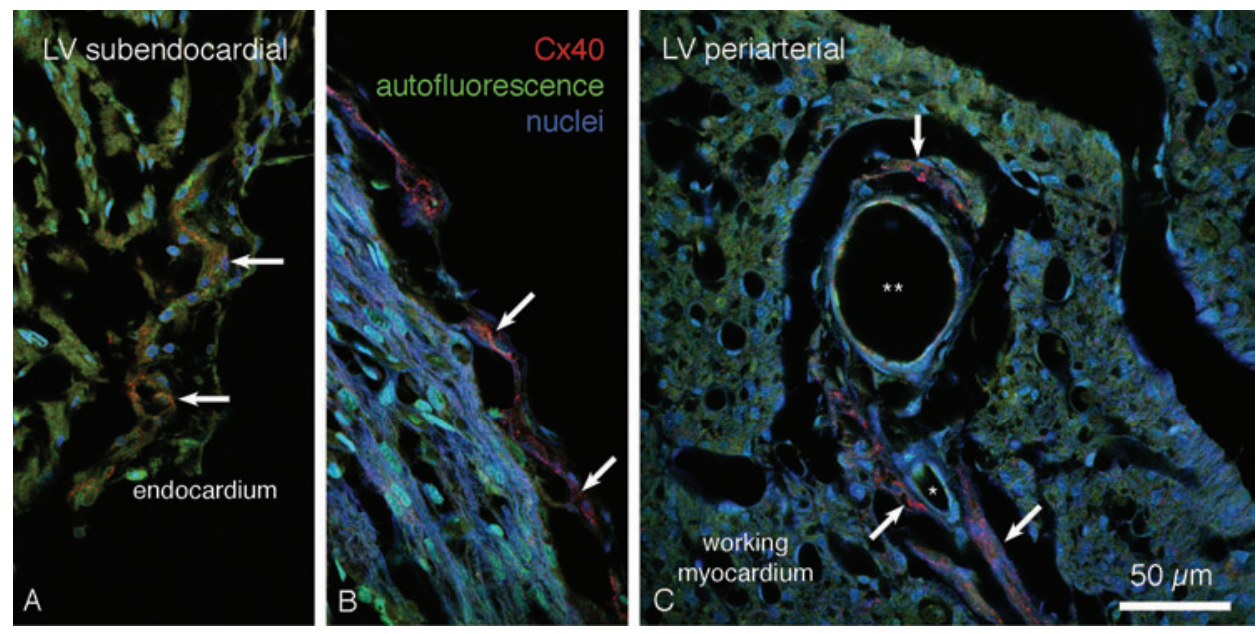

Fig. 4. Purkinje fibers in the ED17 chick embryonic heart. Similar to ungulates, there are both subendocardial (A, B) as well as intramural (C) Purkinje cells; the later are located periarterially. Coronary arteries are labeled with asterisks.

\section{Current state of the art future perspectives}

As a closing paragraph, we would like to provide some insight into some potentially fruitful areas of active reseach of Purkinje fibers. First, new morphological markers such as contactin (Pallante et al. 2010) allow us better delineation of the entire network across species (Ryu et al. 2009), and help to uncover signaling pathways directing their differentiation from the working myocytes in mammals such as notch signaling (Rentschler et al. 2012). This would be important to resolve the issue why some closely related species do or do not possess the intramural component (e.g. rat vs. mouse). Second little explored question is the morphological and functional imaging of contacts and conduction at the Purkinjemyocyte junction, that should be enabled by coupling of these markers with high-speed, high-resolution mapping techniques. Is there a gradual transition of phenotype from clear PF to working myocyte, or is the boundary sharply defined? The third question worthy of attention is the origin and differentiation of Purkinje myocytes. Is the commitment to the conduction lineage irreversible, and if yes, at which point of development? What is the default program of ventricular myocytes - conduction, or working phenotype? Resolution of this particular question would be important piece of information necessary to production of larger pieces of implantable tissue-engineered myocardium.

\section{Conflict of Interest}

There is no conflict of interest.

\section{Acknowledgements}

Author's primary research is supported by the Ministry of Education of the Czech Republic PRVOUK-P35/LF1/5, and institutional RVO: 67985823 from the Academy of Sciences of the Czech Republic. Current support from the Grant Agency of the Czech Republic P302/11/1308 and $13-12412 \mathrm{~S}$ is also gratefully acknowledged. RGG is supported by NIH RO1 HL56728.

\section{References}

AANHAANEN WT, BRONS JF, DOMINGUEZ JN, RANA MS, NORDEN J, AIRIK R, WAKKER V, DE GIER-DE VRIES C, BROWN NA, KISPERT A, MOORMAN AF, CHRISTOFFELS VM: The Tbx2+ primary myocardium of the atrioventricular canal forms the atrioventricular node and the base of the left ventricle. Circ Res 104: 1267-1274, 2009.

AANHAANEN WT, MOMMERSTEEG MT, NORDEN J, WAKKER V, DE GIER-DE VRIES C, ANDERSON RH, KISPERT A, MOORMAN AF, CHRISTOFFELS VM: Developmental origin, growth, and three-dimensional architecture of the atrioventricular conduction axis of the mouse heart. Circ Res 107: 728-736, 2010.

ARGUELLO C, ALANIS J, PANTOJA O, VALENZUELA B: Electrophysiological and ultrastructural study of the atrioventricular canal during the development of the chick embryo. J Mol Cell Cardiol 18: 499-510, 1986.

BETTS TR, HO SY, SANCHEZ-QUINTANA D, ROBERTS PR, ANDERSON RH, MORGAN JM: Threedimensional mapping of right atrial activation during sinus rhythm and its relationship to endocardial architecture. J Cardiovasc Electrophysiol 13: 1152-1159, 2002. 
BOYDEN PA, HIROSE M, DUN W: Cardiac Purkinje cells. Heart Rhythm 7: 127-135, 2010.

BRESSAN M, LIU G, MIKAWA T: Early mesodermal cues assign avian cardiac pacemaker fate potential in a tertiary heart field. Science 340: 744-748, 2013.

BURGGREN WW, CHRISTOFFELS VM, CROSSLEY DA 2ND, ENOK S, FARRELL AP, HEDRICK MS, HICKS JW, JENSEN B, MOORMAN AF, MUELLER CA, SKOVGAARD N, TAYLOR EW, WANG T: Comparative cardiovascular physiology: future trends, opportunities and challenges. Acta Physiol: 2013 (in press).

CHENG G, LITCHENBERG WH, COLE GJ, MIKAWA T, THOMPSON RP, GOURDIE RG: Development of the cardiac conduction system involves recruitment within a multipotent cardiomyogenic lineage. Development 126: 5041-5049, 1999.

CHOI BR, SALAMA G: Optical mapping of atrioventricular node reveals a conduction barrier between atrial and nodal cells. Am J Physiol 274: H829-H845, 1998.

CHRISTOFFELS VM, HOOGAARS WM, MOORMAN AF: Patterning and development of the conduction system of the heart: origins of the conduction system in development. In: Heart Development and Regeneration. ROSENTHAL N, HARVEY RP (eds), Elsevier, London, 2010, pp 171-194.

COPPEN SR, SEVERS NJ, GOURDIE RG: Connexin45 (alpha 6) expression delineates an extended conduction system in the embryonic and mature rodent heart. Dev Genet 24: 82-90, 1999.

DAVIES F: The conducting system of the bird's heart. J Anat 64: 129-146, 1930.

DAVIES F, FRANCIS ET, KING TS: The conducting (connecting) system of the crocodilian heart. J Anat 86: 152-161, 1952.

DAVIES PJ, DONALD JA, CAMPBELL G: The distribution and colocalization of neuropeptides in fish cardiac neurons. J Auton Nerv Syst 46: 261-272, 1994.

DE JONG F, OPTHOF T, WILDE AA, JANSE MJ, CHARLES R, LAMERS WH, MOORMAN AF: Persisting zones of slow impulse conduction in developing chicken hearts. Circ Res 71: 240-250, 1992.

EFIMOV IR, FAHY GJ, CHENG Y, VAN WAGONER DR, TCHOU PJ, MAZGALEV TN: High-resolution fluorescent imaging does not reveal a distinct atrioventricular nodal anterior input channel (fast pathway) in the rabbit heart during sinus rhythm. J Cardiovasc Electrophysiol 8: 295-306, 1997.

ELISKA O: Purkynje fibers of the heart conduction system--history and the present time (in Czech). Cas Lek Cesk 145: 329-335, 2006.

FAZEL AR, SUMIDA H, SCHULTE BA, THOMPSON RP: Lectin histochemistry of the embryonic heart: fucosespecific lectin binding sites in developing rats and chicks. Am J Anat 184: 76-84, 1989.

FEDOROV VV, GLUKHOV AV, CHANG R, KOSTECKI G, AFEROL H, HUCKER WJ, WUSKELL JP, LOEW LM, SCHUESSLER RB, MOAZAMI N, EFIMOV IR: Optical mapping of the isolated coronary-perfused human sinus node. J Am Coll Cardiol 56: 1386-1394, 2010.

GORZA L, SCHIAFFINO S, VITADELLO M: Heart conduction system: a neural crest derivative? Brain Res 457: 360-366, 1988.

GORZA L, VETTORE S, VITADELLO M: Molecular and cellular diversity of heart conduction system myocytes. Trends Cardiovasc Med 4: 153-159, 1994.

GOURDIE RG: A map of the heart: gap junctions, connexin diversity and retroviral studies of conduction myocyte lineage. Clin Sci (Lond) 88: 257-262, 1995.

GOURDIE RG, SEDMERA D: Letter by Gourdie and Sedmera regarding article, "abnormal conduction and morphology in the atrioventricular node of mice with atrioventricular canal-targeted deletion of Alk3/Bmpr1a receptor". Circulation 118: e106; author reply e107, 2008.

GOURDIE RG, GREEN CR, SEVERS NJ, THOMPSON RP: Immunolabelling patterns of gap junction connexins in the developing and mature rat heart. Anat Embryol 185: 363-378, 1992.

GOURDIE RG, GREEN CR, SEVERS NJ, ANDERSON RH, THOMPSON RP: Evidence for a distinct gap-junctional phenotype in ventricular conduction tissues of the developing and mature avian heart. Circ Res 72: 278-289, 1993.

GOURDIE RG, MIMA T, THOMPSON RP, MIKAWA T: Terminal diversification of the myocyte lineage generates Purkinje fibers of the cardiac conduction system. Development 121: 1423-1431, 1995. 
GOURDIE RG, WEI Y, KIM D, KLATT SC, MIKAWA T: Endothelin-induced conversion of embryonic heart muscle cells into impulse-conducting Purkinje fibers. Proc Natl Acad Sci USA 95: 6815-6818, 1998.

GOURDIE RG, HARRIS BS, BOND J, EDMONDSON AM, CHENG G, SEDMERA D, O'BRIEN TX, MIKAWA T, THOMPSON RP: His-Purkinje lineages and development. Novartis Found Symp 250: 110-122; discussion 122-114, 276-119, 2003a.

GOURDIE RG, HARRIS BS, BOND J, JUSTUS C, HEWETT KW, O'BRIEN TX, THOMPSON RP, SEDMERA D: Development of the cardiac pacemaking and conduction system. Birth Defects Res C Embryo Today 69: 46-57, 2003b.

HO SY, ANDERSON RH, SANCHEZ-QUINTANA D: Atrial structure and fibres: morphologic bases of atrial conduction. Cardiovasc Res 54: 325-336, 2002.

HYER J, JOHANSEN M, PRASAD A, WESSELS A, KIRBY ML, GOURDIE RG, MIKAWA T: Induction of Purkinje fiber differentiation by coronary arterialization. Proc Natl Acad Sci USA 96: 13214-13218, 1999.

JAMES TN, SHERF L: Specialized tissues and preferential conduction in the atria of the heart. Am J Cardiol 28: 414-427, 1971.

JENSEN B, BOUKENS BJ, POSTMA AV, GUNST QD, VAN DEN HOFF MJ, MOORMAN AF, WANG T, CHRISTOFFELS VM: Identifying the evolutionary building blocks of the cardiac conduction system. PLoS One 7: e44231, 2012.

KEITH A, FLACK MW: The form and nature of the musclar connections between the primary divisions of the vertebrate heart. J Anat Physiol 41: 172-189, 1907.

KIRBY ML: Cardiac Development. Oxford University Press, New York, 2007, pp 273.

KOMURO H, SAKAI T, HIROTA A, KAMINO K: Conduction pattern of excitation in the amphibian atrium assessed by multiple-site optical recording of action potentials. Jpn J Physiol 36: 123-137, 1986.

KOPRLA EC: The ultrastructure of alligator conductive tissue: an electron microscopic study of the sino-atrial node. Acta Physiol Hung 69: 71-84, 1987.

MEILHAC SM, KELLY RG, ROCANCOURT D, ELOY-TRINQUET S, NICOLAS JF, BUCKINGHAM ME: A retrospective clonal analysis of the myocardium reveals two phases of clonal growth in the developing mouse heart. Development 130: 3877-3889, 2003.

MIQUEROL L, MEYSEN S, MANGONI M, BOIS P, VAN RIJEN HV, ABRAN P, JONGSMA H, NARGEOT J, GROS D: Architectural and functional asymmetry of the His-Purkinje system of the murine heart. Cardiovasc Res 63: 77-86, 2004.

MIQUEROL L, MORENO-RASCON N, BEYER S, DUPAYS L, MEILHAC SM, BUCKINGHAM ME, FRANCO D, KELLY RG: Biphasic development of the mammalian ventricular conduction system. Circ Res 107: 153-161, 2010.

MOMMERSTEEG MT, HOOGAARS WM, PRALL OW, DE GIER-DE VRIES C, WIESE C, CLOUT DE, PAPAIOANNOU VE, BROWN NA, HARVEY RP, MOORMAN AF, CHRISTOFFELS VM: Molecular pathway for the localized formation of the sinoatrial node. Circ Res 100: 354-362, 2007.

OOSTHOEK PW, VIRAGH S, LAMERS WH, MOORMAN AF: Immunohistochemical delineation of the conduction system. II: The atrioventricular node and Purkinje fibers. Circ Res 73: 482-491, 1993.

PALLANTE BA, GIOVANNONE S, FANG-YU L, ZHANG J, LIU N, KANG G, DUN W, BOYDEN PA, FISHMAN GI: Contactin-2 expression in the cardiac Purkinje fiber network. Circ Arrhythm Electrophysiol 3: 186-194, 2010.

RADDATZ E: Response of the embryonic heart to hypoxia and reoxygenation: an in vitro model. Exp Clin Cardiol 2: 128-134, 1997.

RENTSCHLER S, YEN AH, LU J, PETRENKO NB, LU MM, MANDERFIELD LJ, PATEL VV, FISHMAN GI, EPSTEIN JA: Myocardial Notch signaling reprograms cardiomyocytes to a conduction-like phenotype. Circulation 126: 1058-1066, 2012.

ROBB JS: Comparative Basic Cardiology. Grune \& Stratton, New York, 1965, pp 602.

RYU S, YAMAMOTO S, ANDERSEN CR, NAKAZAWA K, MIYAKE F, JAMES TN: Intramural Purkinje cell network of sheep ventricles as the terminal pathway of conduction system. Anat Rec (Hoboken) 292: 12-22, 2009. 
SEDMERA D, RECKOVA M, DEALMEIDA A, SEDMEROVA M, BIERMANN M, VOLEJNIK J, SARRE A, RADDATZ E, MCCARTHY RA, GOURDIE RG, THOMPSON RP: Functional and morphological evidence for a ventricular conduction system in the zebrafish and Xenopus heart. Am J Physiol Heart Circ Physiol 284: H1152-H1160, 2003.

SEDMERA D, RECKOVA M, BIGELOW MR, DEALMEIDA A, STANLEY CP, MIKAWA T, GOURDIE RG, THOMPSON RP: Developmental transitions in electrical activation patterns in chick embryonic heart. Anat Rec A Discov Mol Cell Evol Biol 280: 1001-1009, 2004.

SEDMERA D, WESSELS A, TRUSK TC, THOMPSON RP, HEWETT KW, GOURDIE RG: Changes in activation sequence of embryonic chick atria correlate with developing myocardial architecture. Am J Physiol Heart Circ Physiol 291: H1646-H1652, 2006.

SUMA K: Sunao Tawara: a father of modern cardiology. Pacing Clin Electrophysiol 24: 88-96, 2001.

TAKEBAYASHI-SUZUKI K, YANAGISAWA M, GOURDIE RG, KANZAWA N, MIKAWA T: In vivo induction of cardiac Purkinje fiber differentiation by coexpression of preproendothelin-1 and endothelin converting enzyme-1. Development 127: 3523-3532, 2000.

TAWARA S: Das Reizleitungssystem des Säugetierherzens: eine anatomisch-pathologische Studie über das Atrioventrikularbündel und die Purkinjeschen Fäden. Verlag von Gustav Fischer, Jena, 1906, pp 252.

THOMPSON RP, LINDROTH JR, ALLEN AJ, FAZEL AR: Cell differentiation birthdates in the embryonic rat heart. Ann NY Acad Sci 588: 446-448, 1990.

VICENTE-STEIJN R, PASSIER R, WISSE LJ, SCHALIJ MJ, POELMANN RE, GITTENBERGER-DE GROOT AC, JONGBLOED MR: Funny current channel HCN4 delineates the developing cardiac conduction system in chicken heart. Heart Rhythm 8: 1254-1263, 2011.

VUILLEMIN M, PEXIEDER T, WONG YM, THOMPSON RP: A two-step alignment method for 3D computer-aided reconstruction based on fiducial markers and applied to mouse embryonic hearts. Eur J Morphol 30: 181-193, 1992. 